\title{
OBSERVATIONS ON THE GYMNOSOMATOUS PTEROPOD CLIONE LIMACINA (PHIPPS)
}

\author{
By J. E. MORTON \\ Department of Zoology, Queen Mary College, University of London
}

(Text-figs. I-3)

The Pteropoda Gymnosomata are fast-swimming, shell-less, carnivorous opisthobranchs. The single representative taken at Plymouth is usually regarded as the sexually mature dwarf form of Clione limacina (which replaces the typical boreal form of the species in warmer North Atlantic waters). It turns up frequently in the summer and was first shown by Lebour (I93I) to breed in these waters. The material used in this account was taken alive near Station EI in August, 1953, and was supplemented by a collection very kindly made for me on the cruise of R.V. Sarsia in the Celtic Sea, in September, I956, by Drs J. and Sylvia Gilpin-Brown to whom I am greatly indebted.

Workers on gymnosomes have suffered more than most from the difficulty of seeing well fixed and living material. It was, therefore, thought worthwhile briefly to examine some features of the morphology of this common pteropod that are not adequately known, and to give some notes on its habits in life. After Pelseneer's classic work (1888) came Meisenheimer's 'Valdivia' report (I905), our finest store of information on Gymnosomata. Later workers such as Tesch, Pruvot-Fol, Bonnevie and Massey have concentrated chiefly on the important task of taxonomy, and many details of the morphology and habits are necessarily passed over.

Plymouth specimens of $C$. limacina show well recognizable sexual development at $2.5 \mathrm{~mm}$ long. Lebour (I93I) found eggs being laid by individuals of $5 \mathrm{~mm}$. Like so many opisthobranchs, Clione is protandrous. Fig. 3C (p. 293) shows the size distribution of a sample of 338 specimens from Dingle Bay, west coast of Ireland, September 1956. The smallest size-group (2.5 mm length when fixed) already showed dividing spermatocytes and fully formed sperm in the ovotestis. Only a few undeveloped oocytes were present, as tiny inconspicuous cells at the periphery. Specimens of $3.5 \mathrm{~mm}$ length had most of the sperms mature and stored also in the hermaphrodite duct (see Fig. 3B), while in the largest of the September sample, oocytes were numerous and large (ca. $0.8 \mathrm{~mm}$ ) but no eggs appeared ready to be shed. Even the largest specimens kept the posterior ciliated girdle, a characteristic feature of the dwarf race. The colour was yellowish white and the red patch of the gonad was less intense than in the typical 'northern' form. There is a further difference in the radula, 
the dwarf form having fewer lateral teeth, as was shown by Lebour (I93I) (see also M'Intosh, I898).

C. limacina swims gracefully, either rising vertically or moving forward with the body horizontal. The locomotor organs are a pair of wings set transversely at the anterior fourth of the under side. They are narrowly attached at the

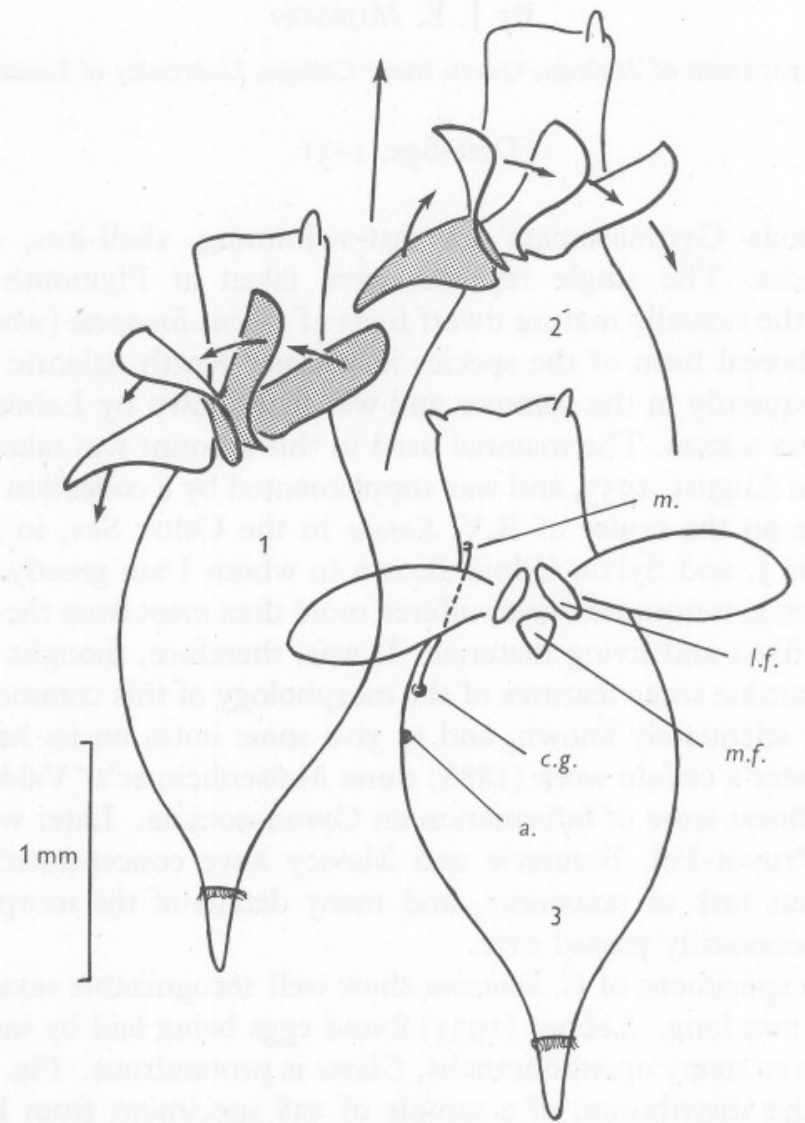

Fig. I. Outline sketches showing the successive positions of the wing in downward (I) and upward (2) strokes (left-side view), and (3) ventral view. $a$, anus; c.g., common genital aperture; l.f., lateral lobe of the vesigial foot; $m$., male aperture; $m$.f., median lobe of the foot.

sides of the mid-line and expand to form broadly rounded flaps. As in all pteropods they are modified parapodia, or outgrowths of the side of the foot. The median part of the foot is vestigial, remaining near the centre in the form of one central and two lateral lobes (Fig. I, m.f., l.f.). Observations on swimming were made from Plymouth material, and I am particularly indebted to Dr J. Gilpin Brown, who observed living Irish specimens, for helping me with the diagrams in Fig. I. The wings move synchronously dorsally and ventrally, 
that is towards and away from the sides of the body. While the smaller thecosomatous pteropod Limacina retroversa (see Morton, 1954) uses its long wings as oars for rowing, Clione employs its shorter wings for sculling. At its narrow attachment to the body the wing makes a small twist after each stroke so that the leading anterior edge is directed relatively more strongly downwards in a down-stroke and upwards on the return. The effect of this is that the ventral surface of the wing faces posteriorly after a down-stroke and the dorsal surface is inclined backwards after recovery. Each stroke is thus given a backward component; while moving ventrally the wing has an upward as well as a forward thrust, compensated by a downward thrust as well as a forward thrust on moving upwards. The beating of the wings is much more rapid than in the thecosomatous pteropod Limacina retroversa, and movements are generally much faster, and the power of quick manoeuvre greater. With the ability to utilize both upward and downward strokes in a sculling action may be related the shorter, rounder wings, and the smaller wing surface found in gymnosomatous pteropods.

The body is perfectly streamlined and Clione has no external gills or excrescences of the skin. Respiration appears to take place through the general body surface, and the whole body cavity forms a wide, blood-filled haemocoele. The circulatory system is extremely simple. The heart, as first described by Meisenheimer (1905), is enclosed in a thin pericardial cavity lying at the posterior part of the visceral mass on the right side. The renal organ, which opens close to the anus, is a thin transparent sac; its walls are neither folded nor glandular.

Like most pteropods, $C$. limacina has the eyes reduced; I could find none at all in serial sections of Plymouth specimens. Gymnosomes, however, find no difficulty in catching zooplankton, and have been generally observed and assumed to feed on thecosomatous pteropods. C. limacina-as with both Plymouth and Irish specimens collected here-generally accompanies larger numbers of Limacina retroversa. The gymnosome buccal mass bears a fine array of hooks, spines, exsertile radular teeth, and adhesive tentacles (cephaloconi) or tentacles bearing suckers (acetabula). These pteropods thus as a group combine some of the efficiency of both cephalopods and chaetognaths. The Clionidae have no acetabula nor jaw, but possess cephaloconi, arranged in a circlet just within the mouth-in Clione limacina three at either side. There is also a pair of long hook sacs, one opening at either side of the pharynx, containing an invaginated cluster of chitinous 'hooks', in this species really slightly curved blades, about fifteen in number. Fig. $2 \mathrm{~B}$ is from a specimen with its buccal armoury everted. So far as is known, the act of food capture has never been described. Observations on this and other habits of the fine gymnosomes of colder seas would be very rewarding. 


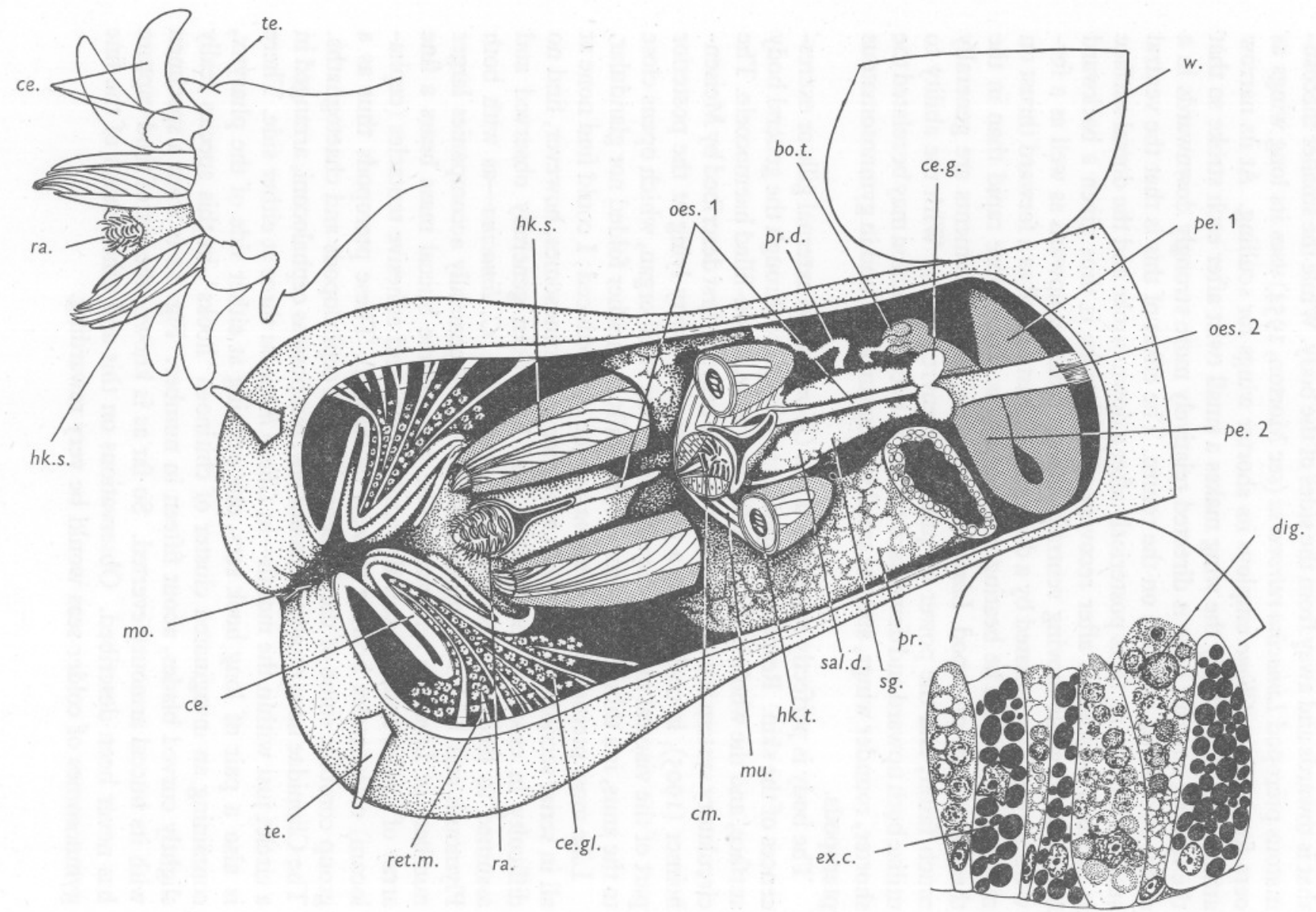

4
0
0
0
0
0
0

Fig. 2. For legend see opposite page. 


\section{ALIMENTARY CANAL}

Fig. 2A explains the structure of the buccal mass. The mouth is a distensible vertical slit, and the prehensile organs-cephaloconi (ce.), hook sacs (hk.s.) and radula $(r a$.) - lie within it, and are everted, in that order. The three cephaloconi on either side are withdrawn into a recess at the side of the buccal cavity when out of use. The epithelium of the cones carries rod-like sensory cells, and their cavities and the adjoining cephalic haemocoele are filled with clusters of unicellular glands, having long ducts and staining blue in azan. Their secretion is assumed to be adhesive (see also Pelseneer, I885). Slips of retractor muscle extend into the cones from the body wall, while they are evidently extruded by the pressure of blood. The hook sacs are ovoid to cylindrical tubes, longer than the pharynx in Clione and opening into it at the sides of the odontophore. Hooks of gradually increasing size are inserted on the mesial wall of the sac, each with a secretory cell underlying it, so arranged that all, including the shortest, protrude into the pharynx. The wall of the sac has a complex musculature, circular outside and longitudinal round the lumen. The hooks can evidently be everted and spread out rather more freely than can be appreciated from Fig. 2B, where the hook sacs themselves are probably extruded rather beyond the natural distance from the mouth. The radular sac runs back between and slightly below the hook sacs, lying in a groove above the two-rodlike cartilages which form the body of the odontophore. The teeth are well figured both by Pruvot-Fol (1926) and Tesch (1950). Slight differences in the serrations of the median tooth in the figures of various authors are to be attributed to different amounts of wear in the teeth at the front of the radula. The main prehensile teeth are those of the lateral rows, which can be strongly erected as the radula protrudes. The salivary glands (sg.) are long straps running forward to open into the pharynx at the sides of the radular sac. These pass with the oesophagus through the nerve ring. Their cells are filled distally with granules staining black in haematoxylin and red in azan. Subepithelial

\section{Legend to Fig. 2}

Fig. 2. A. Stereogram of the head of Clione limacina, opened to show the buccal organs and the male genitalia lying within it The buccal cavity has been opened, and the oesophagus, radular sac and hook sacs cut across in transverse section. The distal part of the prostate gland has been removed, to display the penis sheath lying ventrally to it. Except for the cerebral ganglia, details of the nervous system are left out. $\times c a .90$. B. The buccal organs protruded from the mouth. Drawn from a preserved specimen. c. Histology of the digestive gland. bo.t., 'bouton terminale', where prostatic duct opens into penis sheath; ce., cephalocone; ce.g., cerebral ganglion; ce.gl., glands at base of cephalocone; cm., radular caecum seen in section; dig., digestive cell; ex.c., excretory cell; hk.s., hook sac; hk.t., hook sac in section; mo., mouth; mu., transverse muscles between hook sacs; oes. I, anterior part of oesophagus; oes. 2 , posterior part of oesophagus; pe. I, part of the penis sheath containing the penis; pe. 2 , prostatic part of the penis sheath; pr., prostate; pr.d., duct of the prostate; ra., radula; ret.m., slips of retractor muscles of the cephalocones; sal.d., salivary duct; sg., salivary gland; te., head tentacle; $w$., base of swimming wing (cut short). 
mucus glands open through the sides and floor of the buccal cavity in front of the odontophore.

The rest of the alimentary canal is extremely simple. The oesophagus is narrow, but with deep extensible folds, and leads back to a large stomach-like sac. This bag is formed by two massive brown or blackish coloured digestive diverticula; the posterior one is larger, and extends farther back, especially on the right upper side, and the smaller diverticulum opens from its deeper aspect as a pocket. The true stomach-as in most carnivorous opisthobranchs-is reduced, but to a greater extent in Clione than described anywhere else. It forms a mere funnel of ciliated epithelium on the right side of the digestive sac from which the short intestine runs forward to the body wall. The intestine is a narrow, strongly ciliated tube, and the relatively slight faecal waste is discharged without any mucus binding.

The digestive epithelium with which the 'stomach' is lined has two types of cell (Fig. 2C). The first is long and columnar, with the typical histology of molluscan absorptive-digestive cells. The cytoplasm contains vacuoles filled with particles of varying sizes staining purplish blue in azan, and especially concentrated near the broader free ends of the cells, where there is much diffuse material taken up from the lumen. The intact cell has a narrow striated border. Small spherules from it are constricted off at times into the lumen. The other type of cell, less than half as numerous, is filled with rounded spherules, jet black in haematoxylin, bright red after azan. On general grounds these cells are probably enzyme secreting; from the nature and bulk of the meal, there is obviously much extracellular digestion, and the gut has no other likely source of secretion. The only alternative function to be considered is excretion, since the kidney, a smooth oval sac lying on the right side, has lost all its glandular character. Amoebocytes, however, are distributed subcutaneously, and it may be that these-as in many other molluscs-are able to eliminate waste directly through the body wall.

\section{REPRODUCTIVE SYSTEM}

The genital ducts of Clione have never been described in detail. Fig. 3A illustrates the form and arrangement of the hermaphrodite reproductive system, which is laid out on the plan of primitive opisthobranchs. The ovotestis is a conical sac lying behind the other viscera. Its central part is chiefly a testis, and in older animals ( $3 \mathrm{~mm}$ and above) the periphery is crowded with small acini containing developing oocytes. A narrow hermaphrodite duct, which can be distended as a vesicula seminalis for outgoing sperm, leads forward to the glandular ducts, which fall into two parts. The first is the small, flattened albumen gland (alb.) into which the hermaphrodite duct opens directly, and through which both ova and sperm must pass. It is lined with large squarish cells, staining pink at the base and with the secretion spherules blue after azan. 


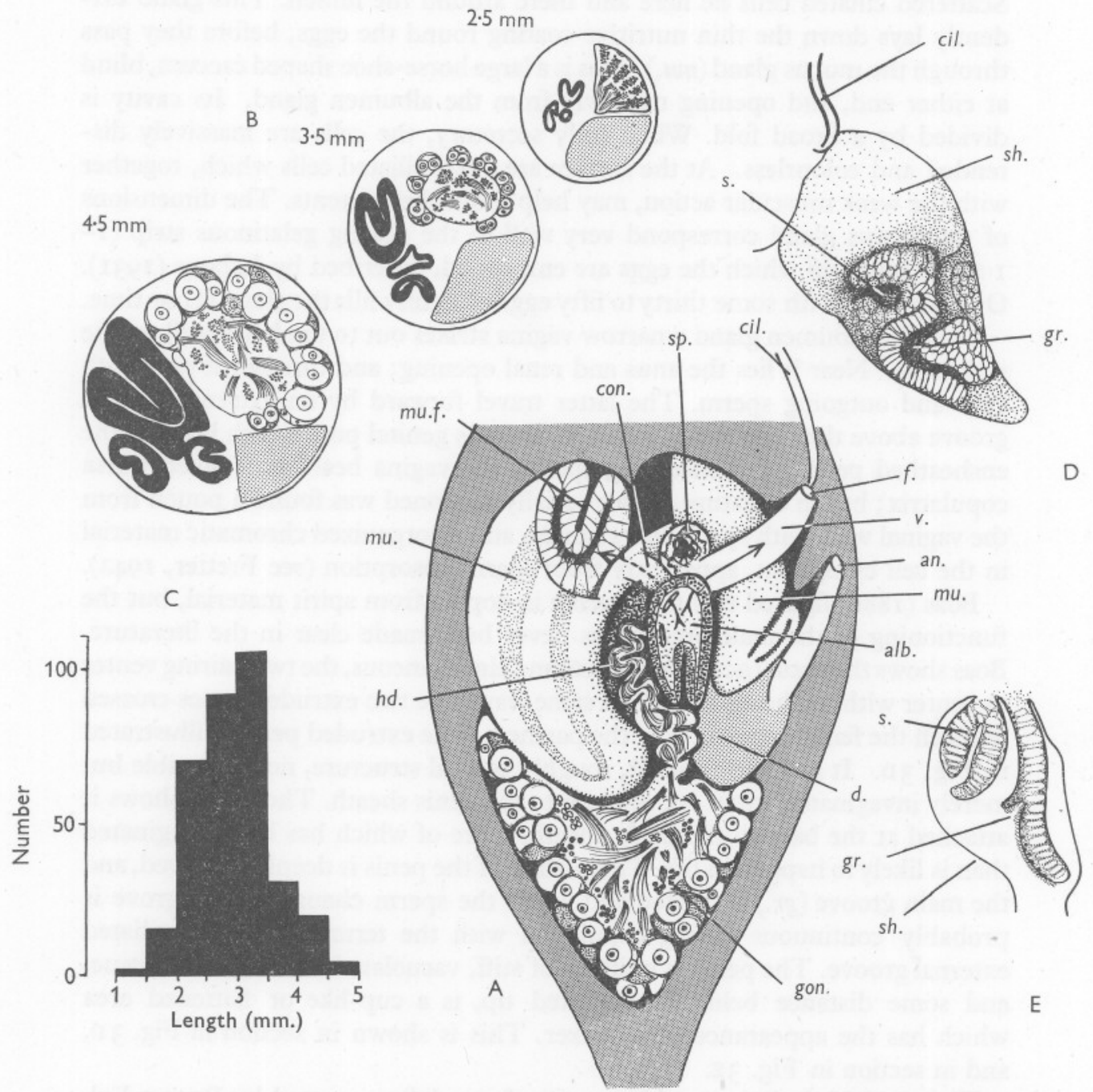

Fig. 3. A. Stereogram of the gonad and genital ducts, in relation to the outline of the body. The gonad and albumen gland are viewed as by transparency, and the mucus gland is cut across to show its internal fold. A more anterior portion of the gonad overlies the genital ducts and has been removed. $\times$ I0. B. Diagrammatic transverse sections showing the size and contents of the gonad in specimens of $2.5,3.5$ and $4.5 \mathrm{~mm}$ length. The genital duct is shown in black, the digestive gland stippled. c. Histogram showing size distribution of a September sample of 338 individuals from the Celtic Sea. The lengths were measured after preservation in formalin. D. Structure of the penis, everted together with part of its sheath. E. The penis within its sheath, in longitudinal section. alb., albumen gland; an., anus; cil., ciliated seminal groove running to male aperture; con., connecting duct between the albumen and mucus glands; $d$., portion of the digestive gland, after removing the rest of the alimentary canal; $f$., common genital aperture; gon., gonad; gr., seminal groove running along the penis; $h d$., hermaphrodite duct, filled with sperm; $m u$., mucus gland; $m u$.f., internal fold of the mucus gland; s., suckerlike appendage of the penis; sh., penis sheath; sp., pouch attached to the vagina, containing sperm; v., vagina. 
Scattered ciliated cells lie here and there around the lumen. This gland evidently lays down the thin nutritive coating round the eggs, before they pass through the mucus gland $(m u$.). This is a large horse-shoe shaped caecum, blind at either end, and opening narrowly from the albumen gland. Its cavity is divided by a broad fold. When fully secretory, the cells are massively distended and colourless. At the surface are a few ciliated cells which, together with the weak muscular action, may help move the contents. The dimensions of the mucus gland correspond very well to the oblong gelatinous strip (II. $2 \mathrm{~mm}$ long), in which the eggs are embedded, described by Lebour (I93I). One egg strip with some thirty to fifty eggs evidently fills the gland at one time.

Fom the albumen gland a narrow vagina strikes out to the body wall on the right side. Near it lies the anus and renal opening; and through it pass both eggs and outgoing sperm. The latter travel forward by an external ciliated groove above the right wing, to enter the male genital pore which leads to the ensheathed penis. For incoming sperm, the vagina bears no stalked bursa copulatrix; but in a mature female serially sectioned was found a pouch from the vaginal wall, with sperm in its lumen, and disorganized chromatic material in the cell cytoplasm, apparently from sperm absorption (see Fretter, 1942).

Boas (1886) figured two C. limacina in copula from spirit material, but the functioning of the male organs has never been made clear in the literature. Boas shows the sexual act as reciprocal and simultaneous, the two pairing venter to venter with the heads facing the same way. The two extruded penes crossed to reach the female apertures of the partners. The extruded penis is illustrated in Fig. 3D. It is a fairly robust, roughly conical structure, not inversible but merely invaginated when out of use into the penis sheath. The figure shows it attached at the base to the penis sheath, more of which has been evaginated than is likely to happen in life. The surface of the penis is deeply furrowed, and the main groove $(g r$.$) is ciliated and forms the sperm channel. This grove is$ probably continuous during copulation with the terminus of the ciliated external groove. The penis is built up of stiff, vacuolated, cartilage-like tissue, and some distance behind its pointed tip, is a cup-like or flattened area which has the appearance of a sucker. This is shown in section in Fig. 3D, and in section in Fig. $3 \mathrm{E}$.

Wagner (1885) gives an odd account of copulation, quoted by Pruvot Fol, in which he claims that an individual $B$ takes semen from a partner $A$ and hands it on to a third individual $C$ (!). Fresh study of copulation in life is much to be desired, but even from careful anatomical study, it would seem that some of the things claimed in the literature are very unlikely. Eschricht (I838), followed by several others, figured the penis with a second branch, a long slender arm carrying a 'sucker' at its tip. This structure-which I have found everted in several preserved specimens-seems to be merely an artefact due to the over-evagination of the penis sac, carrying with it part of the prostatic duct. This duct opens into the penis sheath by a button-like sphincter called 
by Kwietniewski (1903) the 'bouton terminale', which has been regarded as the 'sucker' when evaginated. It is unlikely that such evagination ever happens in life, and the whole 'arm' is thin and flaccid, certainly useless as a prehensive organ. If indeed the copulating animals must secure a firm hold on the smooth body of the partner, the shallow acetabulum on the body of the penis would be better adapted for this role.

The prostate evidently contributes its secretion to the semen by pouring it into the penis sheath, close to the base of the male organ. It opens there by a narrow, slightly coiled duct, discharging through the sphincter (bo.t.) called the 'bouton terminale'. The prostate itself is a massive strap-shaped appendage, extending forward from its duct, then transversely beneath the buccal mass, and finally backward on the left to fill all the space dorsal to the penis sheath. The gland was termed the 'foot-gland' by Pruvot-Fol (1926) but was correctly recognized by Kwietniewski. Its histology resembles very closely that of Otina otis, described by Morton (1955), the cells being very large and filled distally with large blue-staining (azan) aggregates of secretion.

\section{AFFINITIES OF GYMNOSOMATA}

Pelseneer (I888) first clearly distinguished the thecosomatous and gymnosomatous pteropods as separate stocks. From various evidence he held that the Thecosomata were specialized bullomorphs, a view that has commanded wide support ever since. The Limacinidae, with multi-spired sinistral shell and operculum, may well have arisen as pelagic neotenic bulloids (see Lemche's account (1948) of tectibranch larval shells). Pelseneer then demonstrated that swimming wings might have arisen by the enlargement of the parapodia seen in Aplysia-itself an inexpert swimmer-or in Akera, and suggested an aplysioid origin for the Gymnosomata. In his book of 1906 he abandons the Pteropoda as a formal grouping and places his six families of Gymnosomata in the Aplysiomorpha.

Later workers, such as Thiele (I93I), Odhner (I939), and Hoffmann (I939) have revived the order Pteropoda, to include both the shelled ciliary-feeding Thecosomata and the naked carnivorous Gymnosomata. Thus, by overstressing the one resemblance in the possession of wings, very great differences are minimized and a wholly unnatural group erected in the Opisthobranchia. But the Gymnosomata, different though they are from thecosomes, are not readily acceptable as aplysiomorphs. The Anaspidea of Thiele (or Aplysiomorpha) are a small group with a well marked aspect and a rather narrow radiation, which - thanks to the work of Eales and others-we can now well recognize. They are bottom-dwelling herbivores, swimming temporarily by parapodia, and with the restoration of the Akeratidae (Morton \& Holme, 1955) consist of two families. Of the aplysioid characters of the gut, with a well marked crop, double gizzard and caecum, there is not a hint in gymnosomes. Pelseneer 
compared the spinose jaw of Aplysia with the deep hook sacs of gymnosomes, but of the acetabula, cephalocones and gymnosome radula the aplysioids offer no suggestion. The nervous systems and genitalia (see Eales, I92I, and Pruvot Fol, I926) are likewise only comparable at the most general level.

Pelseneer placed much reliance of the ability on aplysioids to swim; but we now know that, if any accomplishment of the opisthobranchs can be credited to parallel evolution, it is this one-a specialization met with in primitive members of every group having parapodia (Arthessa and Oxynoë in the Sacoglossa, Gastropteron in the Bullomorpha, as well as in pleurobranchoids). Akera provides a model of how gymnosome swimming may have arisen, but denotes no close connexion. The gymnosomes are in short a specialized and very distinct group. It may be better to give both Thecosomata and Gymnosomata the status of separate orders, the course most recently followed by Pruvot Fol (1954). If we are to keep them together it must be a marriage of convenience liable to be broken up as soon as more compatible allies can be found.

\section{SUMMARY}

Some features of the digestive and reproductive systems, as well as the habits and swimming of the pteropod Clione limacina have been studied from specimens of the dwarf 'southern' race, which occurs at Plymouth. The animal swims rapidly by the sculling action of its two short rounded 'wings' or parapodia. Its buccal mass is characterized by specialized prehensile organs, consisting - as well as the radula - of adhesive tentacles (cephaloconi) and a pair of hook sacs. The rest of the gut is simple, consisting chiefly of a 'stomach' formed by two spacious digestive diverticula, that have replaced the true stomach. The lining includes absorbing-digestive cells and excretory cells. C. limacina is a protandrous hermaphrodite. The size distribution of a sample of 338 is shown. The youngest specimens are all males; in older groups developing oocytes are found, and in the largest are eggs not yet ready for shedding (September), as well as sperms. The genital tract is of the primitive opisthobranch form, with a sperm-storing hermaphrodite duct, albumen gland and mucus gland. An external seminal groove leads forward to the penial sheath in the head. The structure of the penis and prostate is described, and some previous views on the nature and functioning of these parts are criticized. Finally, the relationships of the gymnosomatous and thecosomatous pteropods are briefly reviewed, and the use of separate orders is recommended in place of the recently revived single group Pteropoda. 


\section{REFERENCES}

Boas, J. E. V., I886. Zur Systematik und Biologie der Pteropoden. Zool. Fb., Bd. I, pp. 3 II -40 .

Eales, Nellie B., I921. Aplysia. Mem. Lpool mar. biol. Comm., No. 24, 92 pp., 7 pl.

Eschricht, D. F., I838. Anatomische Untersuchungen über die Clione borealis. Kopenhagen. 65 pp.

FRETTER, VERA, I942. The genital ducts of some British stenoglossan prosobranchs. F. mar. biol. Ass. U.K., Vol. 25, pp. I73-2II.

HoffmanN, H., 1939. Opisthobranchia (part 7). Bronn's Tierreich, Bd. 3, Abt. 2, Buch 3, Lief. 7, pp. I105-247.

KWIETNIEWSKI, C., I903. Contribuzione alla conoscenza anatomo-zoologica di Pteropodi Gimnosomi di Mare Mediterraneo. Ric. Lab. Anat. norm. Univ. Roma, Vol. 9.

Lebour, MARIE V., I93I. Clione limacina in Plymouth waters. F. mar. biol. Ass. U.K., Vol. 17, pp. 785-95.

LemCHE, H., I948. Northern and Arctic tectibranch gastropods I-II. Kgl. Danske Selsk. Biol. Skr., Vol. 5, (3).

Meisenheimer, J., I905. Pteropoda. Wiss. Ergebn. 'Valdivia', Bd. 9, pp. 3 I4.

M'Intosh, W., I898. Notes from the Gatty Marine Laboratory, St Andrews. I. On the larval stages of Clione limacina. Ann. Mag. nat. Hist., Ser. 7, Vol. 2, pp. 103-5.

Morton, J. E., I954. The biology of Limacina retroversa. F. mar. biol. Ass. U.K., Vol. 33, pp. 297-312.

- 1955. The functional morphology of Otina otis, a primitive marine pulmonate. F. mar. biol. Ass. U.K., Vol. 34, pp. I13-50.

Morton, J. E., \& Holme, N. A., I955. The occurrence at Plymouth of the opisthobranch Akera bullata, with notes on its habits and relationships. F. mar. biol. Ass. U.K., Vol. 34, pp. IOI-I2.

ODHNER, NILs HJ., I939. Opisthobranchiate Mollusca from the western and northern coasts of Norway. K. norske vidensk. Selsk. Skr., No. I, 93 pp.

PelseneER, P., I885. The cephalic appendages of the Gymnosomatous Pteropoda, and especially of Clione. Quart. F. micr. Sci., Vol. 25, pp. 49I-509.

— 1888. Report on the Pteropoda collected by H.M.S. Challenger. III. Anatomy. Rep. 'Challenger', Vol. 23, 132 pp.

- 1906. Mollusca. A Treatise on Zoology, ed. E. Ray Lankester, Vol. 5. London. PRUvoT-Fol, A., 1926. Mollusques ptéropodes gymnosomes provenant des campagnes du Prince Albert I de Monaco. Résult. Camp. sci. Monaco, Fasc. 70, pp. I-60.

- 1954. Mollusques opisthobranches. Faune Fr., No. 58, 460 pp.

Tesch, J. J., 1950. The Gymnosomata. II. Dana Rep., Vol. 36, pp. I-55.

ThIELE, J., I93I. Handbuch der systematischen Weichtierkunde. Bd. 2. Jena.

WAGNER, N., I885. Die Wirbellosen des Weissen Meeres. Leipzig. 